\title{
Health in Digital Era 4.0: Analyzing Reader Engagement Rate on Instagram Account of Government Health Agencies
}

\author{
* $1^{\text {st }}$ Adri Priadana \\ Department of Informatics \\ Universitas Jenderal Achmad Yani \\ Yogyakarta \\ Yogyakarta, Indonesia \\ adripriadana3202@gmail.com \\ $3^{\text {rd }}$ Puji Winar Cahyo \\ Pusat Studi dan Layanan Analitik Data \\ (PuSLAD) \\ Universitas Jenderal Achmad Yani \\ Yogyakarta \\ pwcahyo@gmail.com
}

\begin{abstract}
In recent years, social media has become an essential part of governance in the Digital Era 4.0. The government health agencies, which are an element of implementing government affairs in the health sector, have also utilized social media in disseminating information related to health. Instagram is one of the media used by organizations to disseminate health information. Reader engagement rate can be used as a parameter in measuring the effectiveness of each health service in disseminating information through Instagram. This study aims to analyze the reader engagement rate of several government health agencies' Instagram accounts by measuring engagement score. This study used web scraping techniques to collect data from Instagram such as the number of follower, like, comment, and post. The data was taken in one year, namely post data from 1 January 2019 to 1 January 2020, totaling 3689 data post from ten government health agencies' accounts. Based on the results of this study, the Government Health Agency of Central Java Provincial has the highest engagement score of 20,30 . Therefore, it can be concluded that the dissemination of information carried out by the agency through Instagram can reach a number of readers more effectively than the other nine agencies.
\end{abstract}

Keywords - health in digital era 4.0, reader engagement rate, Instagram account, government health agencies

\section{INTRODUCTION}

In recent years, social media has become an essential part of governance in the Digital Era 4.0. The government adopts social media to provide complementary information dissemination, communication, and participation channels through which citizens can access government officials and make decisions based on that information [1]. The government health agencies, which are an element of implementing government affairs in the health sector, have also utilized social media in disseminating information related to health. The rapid development of online healthcare social websites has supported consumers' healthcare information searching by significantly reducing barriers to healthcare information [2].

\author{
$2^{\text {nd }}$ Andika Bayu Saputra \\ Department of Informatics \\ Universitas Jenderal Achmad Yani \\ Yogyakarta \\ Yogyakarta, Indonesia \\ dika.putra21@gmail.com \\ $4^{\text {th }}$ Muhammad Habibi \\ Pusat Studi dan Layanan Analitik Data \\ (PuSLAD) \\ Universitas Jenderal Achmad Yani \\ Yogyakarta \\ muhammadhabibi17@gmail.com
}

Research by Jordan et. all di 2018 [3], tried to review using Twitter for public health surveillance from monitoring and prediction to public response. This state-of-the-art review demonstrates the vast potential of utilizing Twitter for public health surveillance purposes. Another research by Chen et. all in 2018 [4], found that people with lower health literacy were more likely to use and trust health information from social media and blogs or celebrity webpages where information accuracy and quality are less likely to be assured. Therefore, the government health agencies, as a public health professional, need to improve perspectives and skills to use advanced technology for the benefit of population health in the digital era 4.0 [5]. Besides, government health agencies also need to utilize technology such as social media to reach communities consisting of diverse cultures. Research by Song et. all in 2016 [6], found that cultural differences could influence perceptions concerning health information seeking through social media sites. Online social media platforms represent a promising opportunity for public health promotion [7].

Instagram is one of the fastest-growing social media in recent years [8]. Instagram is a popular social media that is used to share information in the form of images. Instagram is one of the media used by organizations to disseminate health information. Research by Boulos et. all in 2016 [9], said that Instagram allows health organizations to visually reach out and spread public health messages to hundreds of millions of users. In Indonesia, government health agencies have also used Instagram to disseminate information about health to the public. The government health agencies create an official account on Instagram to build user confidence in published health information.

The engagement rate is a key criterion for assessing the effectiveness of social media accounts [10]. It becomes a basis that the reader engagement rate can be used as a parameter in measuring the effectiveness of each health service in disseminating information through Instagram. The more active communication, the more effective the 
information delivery method applied. User engagement on social media can be done to leverage active and passive communication [11]. User engagement contributes to and influences the virality of information on social media [12]. Moreover, user engagement can build users' trust in health providers [13].

Usually, the engagement rate is calculated by measuring the percentage of people who react to a post in a certain way, such as by "liking" or commenting on it [14]. Besides, the number of followers is an essential parameter in this case. However, the account which has a high amount of followers' count does not promise to provide a good engagement rate according to the consumer research done by Lalwani and Shavitt in 2013 [15]. Based on a study done by Peters et.al in 2013 [16], having numerous followers does not guarantee their post will reach their followers. In contrast, activities such as liking, commenting, sharing, or following is a form of proof that content in a post is being read by their followers [17]. Referring to a study done by Ward in 2016 [18], reader engagement can be measured through the number of likes and the number of comments on a post. Therefore, it is better to measure the effectiveness of the health department in disseminating information through Instagram based on reader engagement rate but not the number of followers.

Instagram itself has a free feature called InstagramInsight. This feature is used to analyze data, posts, and stories and provide information about followers (such as gender, age, and geographical location). By using InstagramInsight, we can find out the number of users who liked and commented on the post. Unfortunately, this tool is not open source, which limits the flexibility to use the tool [19]. Besides, this feature can only be used to find out the reader engagement of each account. That makes us unable to directly compare the level of reader engagement between one account and another.

Based on these problems, this study aims to analyze the level of reader engagement of several government health agencies' Instagram account by utilizing Web scraping techniques to collect data from Instagram. Research on analyzing engagement rates on Instagram has been conducted previously by several researcher. Yew et.al in 2018 [20], analyzed influencers on Instagram to get a better understanding of how to use parameters such as followers, comments, and likes, to calculate the engagement rate of influencers in the most accurate way. Recent work by Azmi and Budi in 2018 [21], analyzed the engagement rate of each Indonesia government ministries on Instagram. They used a year of Instagram data that was posted from 1 January 2016 till 31 December 2016. The research showed that the engagement level of the people does not correlate with the frequency of Instagram ministries post. More recent work by Pratiwi et.al in 2019 [22], analyzed Instagram content in tertiary institutions based on engagement rate. The research aims to describe the reflection of the image conducted by Dian Nuswantoro University through its uploads on Instagram accounts@udinus_smg in 2017 and 2018. The results of these studies can be a suggestion for institutions or institutions to improve their promotion strategies through Instagram.

In this study, we implemented Web Scraping to collect data from the Instagram web. This technique is a process to extract data from internet [23]. In this research, web scraping is used to retrieve data such as post time, the number of users who liked and commented on the post from accounts on Instagram automatically. In recent years, the application of web scraping in extracting data from the internet has become one of the dominant studies in the field of social media, especially Instagram. Dorle and Pise in 2018 [24], applied web scraping to collect data from Twitter and Facebook. The purpose of the research is analyzing political sentiment 2019 [25], has applied web scraping to gather the number of replies for quoted tweets to predict message level contagion in social media. In the Instagram platform, the application of web scraping to collect data has been done in several previous researches. Priadana and Habibi in 2019 [8], applied web scraping to collect images from Instagram. The purpose of the research is detecting face to filter selfie face image on search results based on Hashtags on Instagram. More recent work by Habibi and Cahyo in 2019 [26], applied web scraping to collect data from Instagram accounts. The purpose of the research is to clustering user characteristics based on the influence of Hashtags on the Instagram platform. Based on the four studies discussed earlier, it was obvious that the implementation of web scraping in social media, especially in the Instagram platform gain attention from researchers.

\section{MATERIAL AND METHOD}

The process of measuring the engagement score of several government health agencies' Instagram account in this research consists of two sub-processes, namely collecting data and measuring engagement score. The steps of measuring engagement score are shown in "Fig. 1".

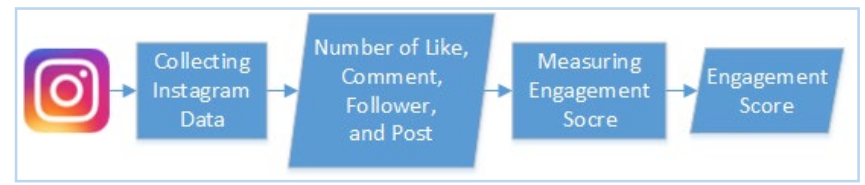

Fig. 1. Process of measuring engagement score

\section{A. Collecting Instagram Data using Web Scraping}

Web scraping is the set of techniques used to automatically get some information from a website [27]. It collects unstructured or semi-structured information from the World Wide Web [28]. In this study, we collected some data from government health agencies accounts on Instagram. Fig. 2 , illustrates one of government health agencies account on Instagram.

The stages developed in this study are [29]:

- The first stage is the analysis phase. At this stage, the user analyzes the HTML structure of the Instagram website. This stage aims to sort the data and elements to be retrieved.

- The next step is to crawl using scripts from the Beautiful Soup library in the Python programming language. The results of this stage are data collection (the number of followers, posts, likes, and comments) obtained from several government health agencies accounts on Instagram during 2019. Then the data set will be stored in a database. 


\section{B. Measuring Engagement Score}

In this case study, quantitative data analysis is made by applying an equation based on the average of likes per post, the average of comments per post, and the number of followers that are presented to measure Instagram engagement score (IES). By calculating engagement scores, we can find out the engagement rate from an Instagram account. The equation (1) is as follows [30]:

(Likes + Comments)

IES $=$ $x 1000$

\section{Number of Followers}



Fig. 2. A government health agencies account on Instagram

\section{RESULT AND DISCUSSION}

The experiment was carried out by determining ten government health agencies accounts on Instagram, which consist of five provincial government health agencies and five city level of government health agencies. The ten government health agencies account are displayed in Table I.

TABLE I. GOVERNMENT HEALTH AGENCIES INSTAGRAM ACCOUNTS

\begin{tabular}{|c|c|c|}
\hline No & Instagram Accounts & Government Health Agencies \\
\hline 1. & @dinkesdki & DKI Jakarta Province \\
\hline 2. & @dinkesjateng_prov & Jawa Tengah Province \\
\hline 3. & @dinkesjatim & Jawa Timur Province \\
\hline 4. & @diskesjabar & Jawa Barat Province \\
\hline 5. & @dinas_kesehatan_diy & Daerah Istimewa Yogyakarta Province \\
\hline
\end{tabular}

\begin{tabular}{|c|c|c|}
\hline 6. & $@$ dinkeskotabdg & Bandung City \\
\hline 7. & @dinkeskotamalang & Malang City \\
\hline 8. & @dkksemarang & Semarang City \\
\hline 9. & @sehatsurabayaku & Surabaya City \\
\hline 10. & $@$ dinkes.kotatangerang & Tangerang City \\
\hline
\end{tabular}

\section{A. Data of Followers, Likes, Comments, and Post}

The first step in this study is collecting data from the Instagram website using web scraping techniques. The data was taken in one year, namely post data from 1 January 2019 to 1 January 2020, totaling 3689 data posts from ten government health agencies' accounts. The results of collecting Instagram data using web scraping are displayed in Table II. Based on the results of data collection in Table II, it can be seen that the Government Health Agency of DKI Jakarta has the highest number of followers, likes, and comments compared to nine other government health agencies.

\section{B. Reader Engagement Score}

The next step is to calculate the engagement score of each government health agencies' account by using the equation (1). The results of measuring the engagement score of government health agencies' accounts on Instagram are displayed in Table III. The final step is to rank descending engagement scores from these ten accounts. The ranking results of the engagement score of government health agencies' accounts on Instagram are displayed in Table IV. More clearly, the ranking result is shown in Fig 3.

\section{TABLE II. RESULTS OF COLLECTING INSTAGRAM DATA}

\begin{tabular}{|c|c|c|c|c|c|c|c|}
\hline No & $\begin{array}{c}\text { Instagram } \\
\text { Accounts }\end{array}$ & $\begin{array}{c}\text { Number o } \\
\text { Likes }\end{array}$ & $\begin{array}{l}\text { f Number of } \\
\text { Comments }\end{array}$ & $\begin{array}{c}\text { Number } \\
\text { of } \\
\text { Followe } \\
\text { rs }\end{array}$ & $\begin{array}{c}\text { Number } \\
\text { of Post }\end{array}$ & $\begin{array}{l}\text { Average } \\
\text { of Likes } \\
\text { per Post }\end{array}$ & $\begin{array}{c}\text { Average of } \\
\text { Comment } \\
\text { per Post }\end{array}$ \\
\hline 1. & (a)dinkesdki & 153680 & 4052 & 39883 & 580 & 264,97 & 6,99 \\
\hline 2. & $\begin{array}{c}\text { @ dinkeskota } \\
\text { bdg }\end{array}$ & 25141 & 664 & 6971 & 483 & 52,05 & 1,37 \\
\hline 3. & $\begin{array}{c}\text { @sehatsuraba } \\
\text { yaku }\end{array}$ & 26484 & 913 & 6309 & 248 & 106,79 & 3,68 \\
\hline 4. & @diskesjabar & 16882 & 370 & 4288 & 251 & 67,26 & 1,47 \\
\hline 5. & $\begin{array}{c}\text { @ dkksemara } \\
\text { ng }\end{array}$ & 15392 & 571 & 4086 & 200 & 76,96 & 2,86 \\
\hline 6. & $\begin{array}{c}@ \text { dinkes.kota } \\
\text { tangerang }\end{array}$ & 17620 & 813 & 3993 & 299 & 58,93 & 2,72 \\
\hline 7. & @dinkesjatim & 15420 & 242 & 2658 & 331 & 46,59 & 0,73 \\
\hline 8. & $\begin{array}{c}\text { @ dinkesjaten } \\
\text { g_prov }\end{array}$ & 16732 & 688 & 2053 & 418 & 40,03 & 1,65 \\
\hline 9. & $\begin{array}{c}@ \text { dinkeskota } \\
\text { malang }\end{array}$ & 9229 & 184 & 1792 & 771 & 11,97 & 0,24 \\
\hline 10. & $\begin{array}{c}@ \text { dinas_kese } \\
\text { hatan_diy }\end{array}$ & 2064 & 49 & 1110 & 108 & 19,11 & 0,45 \\
\hline \multicolumn{5}{|c|}{ Total Post } & 3689 & 479,69 & 22,16 \\
\hline
\end{tabular}




\section{TABLE III. READER ENGAGEMENT SCORE}

\begin{tabular}{|c|c|c|}
\hline No & Instagram Accounts & Engagement Score \\
\hline 1. & @dinkesdki & 6,82 \\
\hline 2. & @dinkeskotabdg & 7,66 \\
\hline 3. & @sehatsurabayaku & 17,51 \\
\hline 4. & @diskesjabar & 16,03 \\
\hline 5. & @dkksemarang & 19,53 \\
\hline 6. & @dinkes.kotatangerang & 15,44 \\
\hline 7. & @dinkesjatim & 17,80 \\
\hline 8. & @dinkesjateng_prov & 20,30 \\
\hline 9. & @dinkeskotamalang & 6,81 \\
\hline 10. & @dinas_kesehatan_diy & 17,63 \\
\hline
\end{tabular}

TABLE IV. RANKING OF ENGAGEMENT SCORE

\begin{tabular}{|c|c|c|c|c|}
\hline No & Instagram Accounts & $\begin{array}{c}\text { Number } \\
\text { of } \\
\text { Followers }\end{array}$ & $\begin{array}{c}\text { Engagement } \\
\text { Score }\end{array}$ & Ranking \\
\hline 1. & @dinkesjateng_prov & 2053 & 20,30 & 1 \\
\hline 2. & @dkksemarang & 4086 & 19,53 & 2 \\
\hline 3. & @dinkesjatim & 2658 & 17,80 & 3 \\
\hline 4. & @dinas_kesehatan_diy & 1110 & 17,63 & 4 \\
\hline 5. & @sehatsurabayaku & 6309 & 17,51 & 5 \\
\hline 6. & @diskesjabar & 4288 & 16,03 & 6 \\
\hline 7. & @dinkes.kotatangerang & 3993 & 15,44 & 7 \\
\hline 8. & @dinkeskotabdg & 6971 & 7,66 & 8 \\
\hline 9. & @dinkesdki & 39883 & 6,82 & 9 \\
\hline 10. & @dinkeskotamalang & 1792 & 6,81 & 10 \\
\hline
\end{tabular}

Reader Engagement Rate of Government Health Agencies' Instagram Accounts
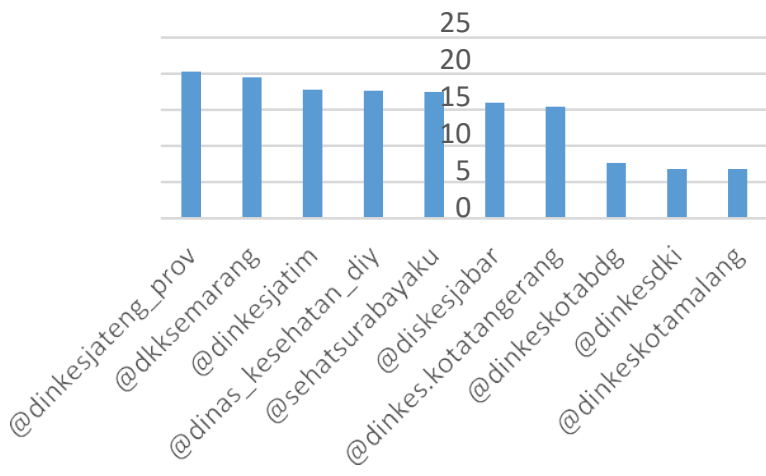

Fig. 3. Engagement rate of government health agencies account on Instagram

Based on the results shown in Table IV, it appears that the Government Health Agency of Central Java Provincial has the highest engagement score of 20,30. Based on the number of followers, the Government Health Agency of Central Java Provincial is ranked eighth. This result shows that a high number of followers does not determine the high engagement score.

\section{CONCLUSION}

This research has succeeded in analyzing the reader engagement rate of several government health agencies' Instagram account by measuring engagement score. The data was taken in one year, namely post data from 1 January 2019 to 1 January 2020 , totaling 3689 data post from ten government health agencies account. Based on the results of this study, the Government Health Agency of Central Java Provincial has the highest engagement score of 20,30. Therefore, it can be concluded that the dissemination of information carried out by the agency through Instagram can reach a number of readers more effectively than the other nine agencies.

\section{ACKNOWLEDGMENT}

This research is in part financially supported by Department of Informatics, Faculty of Teknik dan Teknologi Informasi, Universitas Jenderal Achmad Yani Yogyakarta. Hopefully, this research can bring benefits to the progress of the Indonesian nation, especially the government health agencies in Indonesia.

\section{REFERENCES}

[1] C. Song and J. Lee, "Citizens Use of Social Media in Government, Perceived Transparency, and Trust in Government," Public Perform. Manag. Rev., vol. 39, no. 2, pp. 430-453, Apr. 2016.

[2] L. Jiang and C. C. Yang, "User recommendation in healthcare social media by assessing user similarity in heterogeneous network," Artif. Intell. Med., vol. 81, pp. 63-77, Sep. 2017.

[3] S. Jordan, S. Hovet, I. Fung, H. Liang, K.-W. Fu, and Z. Tse, "Using Twitter for Public Health Surveillance from Monitoring and Prediction to Public Response," Data, vol. 4, no. 1, p. 6, Dec. 2018.

[4] X. Chen et al., "Health Literacy and Use and Trust in Health Information," J. Health Commun., vol. 23, no. 8, pp. 724-734, Aug. 2018.

[5] S. Plianbangchang, "Public Health in the Digital Era: An Overlooked Public Health Issue,” J. Heal. Sci. Altern. Med., vol. 1, no. 1, pp. 1-3, Apr. 2019.

[6] H. Song et al., "Trusting social media as a source of health information: Online surveys comparing the United States, Korea, and Hong Kong," J. Med. Internet Res., vol. 18, no. 3, Mar. 2016.

[7] H. C. Lyson et al., "Social Media as a Tool to Promote Health Awareness: Results from an Online Cervical Cancer Prevention Study," J. Cancer Educ., vol. 34, no. 4, pp. 819-822, Aug. 2019.

[8] A. Priadana and M. Habibi, "Face Detection using Haar Cascades to Filter Selfie Face Image on Instagram," in 2019 International Conference of Artificial Intelligence and Information Technology (ICAIIT), 2019, pp. 6-9.

[9] M. Kamel Boulos, D. Giustini, and S. Wheeler, "Instagram and WhatsApp in Health and Healthcare: An Overview," Futur. Internet, vol. 8, no. 3, p. 37, Jul. 2016.

[10] A. Ruby, L. Perna, R. Boruch, and N. Wang, "Are There Metrics for MOOCS From Social Media?," Online Learn. Off. J. Online Learn. Consort., vol. 19, no. 5, Dec. 2015.

[11] K. Hemmings-Jarrett, J. Jarrett, and M. B. Blake, "Evaluation of User Engagement on Social Media to Leverage Active and Passive Communication," in Proceedings - 2017 IEEE 1st International Conference on Cognitive Computing, ICCC 2017, 2017, pp. 132-135.

[12] J. Berger and K. L. Milkman, "What Makes Online Content Viral?," J. Mark. Res., vol. 49, no. 2, pp. 192-205, Apr. 2012.

[13] F. Alhayan, D. R. Pennington, and S. Ayouni, "Measuring Passive Engagement with Health Information on Social Media," in 21 st Saudi Computer Society National Computer Conference, NCC 2018,2018. 
[14] R. Jaakonmäki, O. Müller, and J. vom Brocke, "The Impact of Content, Context, and Creator on User Engagement in Social Media Marketing," in Proceedings of the 50th Hawaii International Conference on System Sciences (2017), 2017.

[15] A. K. Lalwani and S. Shavitt, "You Get What You Pay For? SelfConstrual Influences Price-Quality Judgments," J. Consum. Res., vol. 40, no. 2, pp. 255-267, Aug. 2013.

[16] K. Peters, Y. Chen, A. M. Kaplan, B. Ognibeni, and K. Pauwels, "Social media metrics - A framework and guidelines for managing social media," J. Interact. Mark., vol. 27, no. 4, pp. 281-298, Nov. 2013.

[17] M. Hellberg, "Visual Brand Communication on Instagram: A study on consumer engagement," Hanken School of Economics, 2015.

[18] J. Ward, "A Content Analysis of Celebrity Instagram Posts and Parasocial Interaction,” Elon J. Undergrad. Res. Commun., vol. 7, no. 1, pp. 44-51, 2016.

[19] A. Alsaeed, O. Alotaibi, N. Alotaibi, and M. Almutairy, "Automating Instagram Activities and Analysis: A Survey of Existing Tools," in Lecture Notes in Computer Science (including subseries Lecture Notes in Artificial Intelligence and Lecture Notes in Bioinformatics), 2019, vol. 11578 LNCS, pp. 267-277.

[20] R. L. H. Yew, S. B. Suhaidi, P. Seewoochurn, and V. K. Sevamalai, "Social Network Influencers' Engagement Rate Algorithm Using Instagram Data," in Proceedings - 2018 4th International Conference on Advances in Computing, Communication and Automation, ICACCA 2018, 2018.

[21] A. F. Azmi and I. Budi, "Exploring practices and engagement of Instagram by Indonesia Government Ministries," in Proceedings of 2018 10th International Conference on Information Technology and Electrical Engineering: Smart Technology for Better Society, ICITEE 2018, 2018, pp. 18-21.

[22] M. R. Pratiwi, S. A. Hapsari, and A. Yusriana, "Refleksi Citra Universitas Dian Nuswantoro Melalui Unggahan di Akun @udinus smg," J. Penelit. Pers dan Komun. Pembang., vol. 23, no. 2, pp. $79-9 \overline{3}, 2019$.

[23] R. C. Pereira and T. Vanitha, "Web Scraping of Social Networks," Int. J. Innov. Res. Comput. Commun. Eng., vol. 3, no. 7, pp. 237$240,2015$.

[24] S. Dorle and N. Pise, "Political Sentiment Analysis through Social Media," in Proceedings of the 2nd International Conference on Computing Methodologies and Communication, ICCMC 2018, 2018, pp. 869-873.

[25] S. Levens, O. ElTayeby, T. Gallicano, M. Brunswick, and S. Shaikh, "Using Information Processing Strategies to Predict Message Level Contagion in Social Media," in Advances in Intelligent Systems and Computing, 2020, vol. 965, pp. 3-13.

[26] M. Habibi and P. W. Cahyo, "Clustering User Characteristics Based on the influence of Hashtags on the Instagram Platform," IJCCS (Indonesian J. Comput. Cybern. Syst., vol. 13, no. 4, pp. 399-408, 2019.

[27] E. Vargiu and M. Urru, "Exploiting web scraping in a collaborative filtering- based approach to web advertising," Artif. Intell. Res., vol. 2, no. 1 , Nov. 2012

[28] F. Kokkoras, K. Ntonas, and N. Bassiliades, "DEiXTo: A web data extraction suite," in ACM International Conference Proceeding Series, 2013, pp. 9-12.

[29] Fatmasari, Y. N. Kunang, and S. D. Purnamasari, "Web Scraping Techniques to Collect Weather Data in South Sumatera," in Proceedings of 2018 International Conference on Electrical Engineering and Computer Science, ICECOS 2018, 2019.

[30] X. Gong, "A Case of Global Business to Customer (B2C) Brands: Strategic Customer Engagement on Instagram," KTH Royal Institute of Technology, 2015. 